\title{
The Advocacy Subjects of Third-party Logistics Contract Void
}

\author{
Xiuli TAN \& Bayi GUAN \\ Yantai Nanshan University, Yantai, Shandong, China
}

\begin{abstract}
Who shall put forward or propose the third-party logistics contract void, about which the three Contract Laws issued have no provisions, this shows it is a legislative gap or knotty problem. This document aims to draw a conclusion that in China one party with logistics contract benefit loss shall put forward the third-party logistics contract void through analysis according to foreign legal provisions and legal basis; After disputing party's lawsuit, the court can review the third-party logistics contract ex officio and confirm the third-party logistics contract invalid, without the restrictions whether the disputing party puts forward thirdparty logistics contract void, so the court can be regarded as the proposer of third-party logistics contract void. KEYWORD: third-party logistics contract; contract void; advocacy; subject
\end{abstract}

\section{THE CONTENT OF THIRD-PARTY LOGISTICS CONTRACT VOID}

Third-party logistics contract refers to an agreement about the establishment, alteration and termination of rights and obligations between the parties involving third-party logistics service. The logistics service contracts (incl. transit, storage, packing, handling, transport, distribution etc.) related to thirdparty logistics contracts belong to civil and commercial contracts in nature. Third-party logistics contract void refers to those signed but without legal force resulting from lack of validity requirement. It is certainly, absolutely and originally void. Contract Law item 52 lists 5 clauses, which are 5 conditions leading to third-party logistics contract void, legal scholars make theoretical argument from many points of view and ways of thinking, civil judges and lawyers shuttle between theory and practice, so as to search for the fit point of theory and actual case. The focus attracting attention is: who on earth have the rights to put forward third-party logistics contract void?

\section{CURRENT SITUATION OF ADVOCACY SUBJECTS FOR THIRD-PARTY LOGISTICS CONTRACT VOID}

Who shall advocate or put forward third-party logistics contract void, it varies from country to country depending on different standpoints of contract void claimer.

\subsection{In France}

French attitude: most of scholars think, the party advocating contract void is the interested party of contract, including contract parties, inheritor of party, particular estate concessionaire and common creditor. But some scholars think this expression is not accurate. Because the validity of contract is not confirmed, it is impossible to confirm particular estate concessionaire and common creditor. In addition, even the parties have advocacy rights, the right is not given to both parties. Generally speaking, only the party with interests loss exercises the advocacy right. Moreover, according to French law, the prosecutor and Administrative organ has the right to initiate contract void in particular cases. As part of special contract law, the third-party logistics contract void continues to use the provisions of general law, it's the same.

\subsection{In Germany}

In Germany, most scholars think contract void behavior is certainly void. The plaintiff can sue confirmation asking Court for confirmation of contract void, but at the same time, the plaintiff shall prove the accusatory interests through the proof; The judge has also the right to declare contract void ex officio; The third party can also apply the court to 
confirm the contract (signed between others) void as the third interests party, who shall also provide evidence proving the accusatory interests existence. Third-party logistics contract void applies to same stipulations.

\subsection{In our country}

In our country, legislation has not specified the advocacy rights of third-party logistics contract invalid. The Economic Contract Law of People's Republic of China enacted in 1981 and amended in 1993. People's Republic of China Contract Law enacted in 1999, which of the provisions of the three legislation have not made the subject of the contract invalid, not to mention the third-party logistics contract terms, a vague idea of the legislature can be seen on this issue. It also stated that this is a legislative gap or a difficult problem; In the judicial practice, it was mostly clear that the parties of thirdparty logistics contract had known the content of third-party logistics contract illegal or not. They are the subjects of proposing third-party logistics contract invalid. But not understanding the law or without legal consciousness, a large number of thirdparty logistics contract's dispute in the proceedings was found invalid and filed by people's court or arbitration body. It was people's court or arbitration body who was the third-party logistics contract invalid filed and confirmed by. In theory, Professor HX Liang believes the filing subjects of the contract invalid are divided into in two categories: First, the subjects of parties. The subject initiative invalid and the court review and invalidate the contract. The other is the court who found that the contracts violated mandatory provisions of law initiative invalid. Professor Wang Liming also hold this view. In this theory, the third party logistics contract invalid on the confirmation applies equally.

So, how to correctly understand the problem of the third-party logistics contract invalid's advocacy subject? Measures will be taken.

\section{THIRD-PARTY LOGISTICS CONTRACT INVALID'S ADVOCACY SUBJECT'S ANALYSIS AND CONFIRMATION IN CHINA.}

\subsection{A party aggrieved}

It was believed by the author that the advocacy subject of the contract invalid of third-party logistics is the one of the contract whose interests was aggrieved.

It is believed that the contract relationship is relative, which was originated form "the relativity of debt "in the early Roman referring to" the wild bunch of state between the parties." In other words, it refers to the effectiveness of the debt can and can only be binding on the both parties. In essentially, the debt, which refers to the legal relationships on which one party requests the other for a certain behavior or not for a certain behavior, so there is not the trace effect of real property rights, but only has an effect on someone. It is one of the types of creditor's rights, so third-party logistics contract also has the relativity which on the parties' subject, the content and responsibility. According to the theory of relativity, the third-party logistics contract invalid can be put forward only by one party aggrieved for the other party.

Can a third person other than the parties of thirdparty logistics contract put forward the third party logistics contract invalid? It was not believed by the author. Firstly, it violates the relativity principle of the third party logistics contract. According to the relativity principle of main body on the third party logistics contract, any third party shall not participate in the contract of the third party logistics; Secondly, according to the relativity of the content of third-party logistics contract, it is only known by the both parties, which of any other person without knowing, because the third person is so difficult to obtain enough evidence that can't prove the third party logistics contract invalid. So if the third person, as the body of the filing invalid, can produce hearsay or suspected of the third-party logistics contract invalid between the both parties; It will increase the workload of the court and the damage to the judicial authority; The third party logistics in terms of the contract the parties will responses to be filed a lawsuit for no apparent reason and prosecuted for the defendant by a third person, involving the energy, time and money. What's more important is to the derogatory remarks about the value of litigation activity; What's most important is that if it violate the creditor's rights of a third person, if the purpose of the third party logistics contract is lost, it hinder the market transaction, disrupt economic order so hard that it will bring a serious series of consequences. Even if the third person is the third party logistics interest parties of the contract, it should also be made according to the provisions of other laws, not involved in the controversy of thirdparty logistics contract invalid. It is based on the above reason, while the third party logistics contract is invalid, of course, from the beginning and determine invalid, in theory, everyone has right to punish, but the practice is not feasible.

\subsection{The limits of exercise of rights of third-party logistics contract invalid}

The aggrieved party of third-party logistics contract though has the advocacy right of third party logistics contract invalid, but it is not at random. As in the logistics financial contract (one of the third party logistics contracts) one logistics company and a 
bank signed the loan contract, when the logistics company was not on borrowing, he said logistics financial contract was invalid and it made many false materials to get the trust of the bank, diddle borrowing, and damage the interests of the state, so the logistics financial contract should be confirmed invalid. If the third-party logistics contract benefits him, he advocates that the contract came into effect; the third-party logistics contract has no benefits to him, he claimed it was invalid. It make clear that it has no regulation on it in Chinese law, but the ban in the common law legal system is taken to stop the unjust phenomena. Ban refers to that it prohibit a party do not match the facts or the right to claim the expression through words or actions before he made, especially when the other party to believe in what he said it had have before. That is to say, if you sign a third-party logistics contract, you should be bound by the third party logistics contract. You can't decide to say that third-party logistics contract is correct if it is favorable to you; third-party logistics contract is invalid if it is unfavorable to you. No special provisions of this law in our country, but according to the principle of good faith in contract law article 6 in our country, it can't set up that third-party logistics contract invalid in this capricious behavior argues which the judge also does not support. So it does not damage the principle of good faith in order to maintain system of invalid.

\subsection{The public power cannot mention reasons for third-party logistics contract invalid.}

If it is found that the third-party logistics contract invalid in the process of administrative law enforcement, the state organs put forward for contract invalid ex officio or directly to the court by themselves?

It is believed that our country does not need to draw lessons from the practice of the French, and on the basis of the practice of Germany by the author. Administrative organs found third-party logistics contract invalid between the parties to resolve it through other concerned channels in the process of law enforcement. The party, for example, shall be penalized by way of administrative punishment. But administrative organs have no right to sue to the court directly, also no right to confirm third-party logistics contract invalid. Because of third-party logistics contract relationship, it is only the both parties who have legal effect and the existence of the interests of litigation. And the administrative organ has no interests of litigation. In the legal theory, the administrative organs cannot be involved in the private fields. In criminal lawsuit, the people's prosecutors are on behalf of the state, maintaining social public interests; In administrative litigation, administrative organs is the representative of the state, maintaining public interests; And in the field of civil and commercial matters, the citizen, legal person is the individual subject, so the third-party logistics contract only have legal effectiveness between the signers, through the negation of thirdparty logistics contract effectiveness between the both parties to maintain the public interest, and the interests of the public does not need to corresponding implementation main body. So the relevant state organs also have no right to represent the "public" to implement filing subject of right of the third party logistics contract invalid. Public power intervention is not allowed in the civil and commercial private law relations, meaning that the state organs may not arbitrarily invaded areas of the civil and commercial law, It adhere to the principle of autonomy of private law already, also maintain the theory of no trial without complaint.

\subsection{According to the power, Judicial review the third-party logistics invalid.}

In the field of civil and commercial cases ineffective, the court judicial organ is in a neutral position. After the parties into the proceedings the court acts as a trial role. At the time of trial life without the restrictions whether the disputing party puts forward third-party logistics contracts void, the court shall have the right to intervene. Only from the perspective of the litigation rights, the parties shall be the only advocacy main part for third-party logistics contract void. Any other state organ including the judicial organ has no right to mention the contract invalidation. It embodies the third-party logistics contract autonomy, against public power intervention; But in litigation, the judicial organ has rights to deal with the dispute of third-party logistics contract void, without the restrictions whether the disputing party puts forward third-party logistics contract void, which does embody the trial neutrality and authority.

\section{CONCLUSION}

Above all, it was believed that the advocacy main part for third-party logistics contract void is the party whose interests have been jeopardized in third -party logistics contract; The parties litigation, the court may review the third party logistics contract in accordance with the authority, confirm the thirdparty logistics contract invalid, without the restrictions whether the disputing party puts forward third-party logistics contract void. Therefore, one of both parties' interests jeopardized in third partylogistics contract and the courts for the advocacy subjects of third-party logistics contract void. 


\section{ACKNOWLEDGEMENT}

This paper is the research result of Social Science and Planning Research Project of Yantai City "Supply Chain's Financial Ecological Environment Optimizing Research in Yantai "key topics: Project Number: ytsk2014-028.

This paper is the research result of Young Teachers Fund Project of Yantai Nanshan University "Financial Model and Risk Management Based on Logistics of Regional Economic Development" (Item Number: 201408).

\section{REFERENCES}

[1] Wang, Z.J.2001. The general civil law. Beijing. China University of Political Science and Law Press.

[2] [America] Godley \& Zhang, G.Y.2006. Beijing. The philosophical origin of the modern contract theory. Law Press.

[3] Luo,W.P \& Tian,Z. 2000. Logistics. Dalian. DaLian Maritime University Press.

[4] Luo,W.P \& Gu,ZH .2006.Third party logistics tutorial. Shanghai. Fu Dan University Press.

[5] Zhou, L.C.2005. Third party logistics organization -- theory and application. Economic Management Publishing House.

[6] Wang, L.M. 1996.Theory of contract relativity. Jurisprudence of China. 